Uluslararası Sosyal Bilgilerde Yeni Yaklaşımlar Dergisi, 2021, 5(1), 46-62

International Journal of New Approaches in Social Studies, 2021, 5(1), 46-62

\title{
Sosyal Bilgiler Öğretmen Adaylarının Dijital Vatandaşlık Algılarının Belirlenmesi*
}

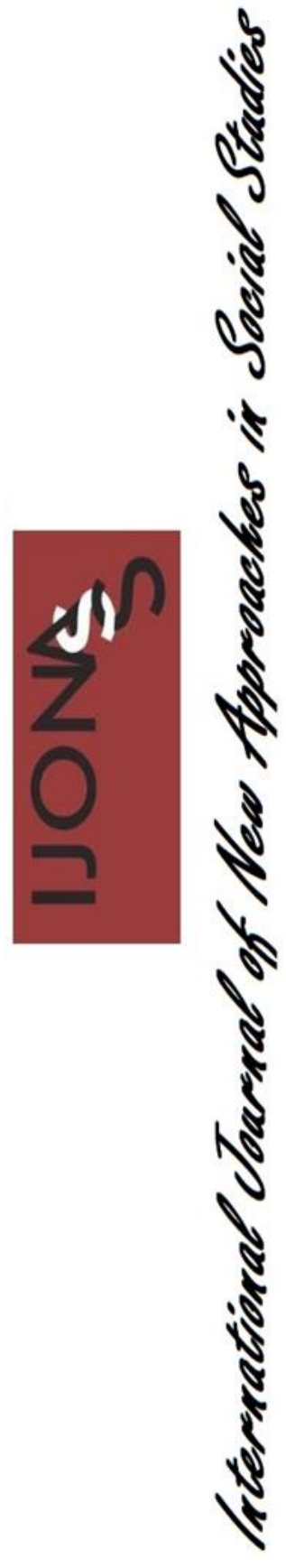

\author{
Emine KARASU AVCI ${ }^{1}$, Melike FAİZ ${ }^{2}$ \& Serpil RECEPOĞLU ${ }^{3 * *}$
}

Gönderilme Tarihi: 23 Ocak 2021

Kabul Tarihi: 05 Mart 2021

DOI: $10.38015 /$ sbyy.866927

$\ddot{O} z:$

Bilgi ve iletişim alanındaki gelişmeler, toplumu önemli ölçüde etkilemektedir. Bilgi iletişim teknolojilerindeki hızl gelişim tüm alanları etkilediği gibi vatandaşlıkla ilgili çalışmaları da etkilemiş ve teknoloji ile ilgili vatandaşlık kavramları ortaya çıkmıştır. Bunlardan biri de dijital vatandaşlık kavramıdır. Dijital vatandaşlık en genel itibariyle teknoloji kullanımına ilişkin hak ve sorumlulukları, etik kurallarl ve interneti etkin ve doğru kullanabilmeyi kapsamaktadır. Gençlerin dijital ortamlarda hak ve sorumluluklarını farkında olmaları, etik kuralların bilincinde olmaları, eleştirel düşünebilmeleri, toplum yararına aktif katılım gösterebilmeleri için dijital vatandaşlık üzerinde durulmasl gereken bir konudur. Sosyal bilgiler dersi bireyin etkin vatandaş olarak yetişmesini hedeflemektedir. Haliyle dijital vatandaşlık becerisini de sosyal bilgiler öğretmenleri etkili bir şekilde verecektir. Bu nedenle sosyal bilgiler ögretmen adaylarının dijital vatandaşlık algılarının tespit edilmesi önemli görülmektedir. Araştırma betimsel tarama modelindedir. Araştırmanın çalışma grubunu 2019-2020 ĕgitim öğretim yllında bir devlet üniversitesinin Ĕ̆itim Fakültesi Sosyal Bilgiler Ĕ̈itimi Anabilim Dalı 1., 2., 3. ve 4. sınıfta okuyan 214 ögrretmen adayı oluşturmaktadır. Araştırmada veri toplamı aracı olarak Kuş, Güneş, Başarmak ve Yakar (2017) tarafindan geliştirilen "Gençlere yönelik dijital vatandaşlık ölçeğì" kullanılmıştır. Araştırmanın bulgularına göre, Sosyal Bilgiler ögretmen adaylarının dijital vatandaşlık algılarına bakıldı̆̆ında orta düzeyin üstünde olduğu saptanmıştır. Sosyal Bilgiler ögretmen adaylarının dijital vatandaşlık algılarının iletişim, güvenlik, etik ve ölçeğin toplam puanında cinsiyet değişkenine göre bir farklılaşmanın olduğu görülmüştür.

Anahtar Kelimeler: Sosyal bilgiler, öğretmen adaylarl, dijital vatandaşlık, algl.

\begin{abstract}
:
Developments in the field of information and communication significantly affect the society. The rapid development of information communication technologies has affected all fields as well as the studies on citizenship and the concepts of citizenship related to technology have emerged. One of them is the concept of digital citizenship. Digital citizenship generally covers the rights and responsibilities regarding the use of technology, ethical rules and the ability to use the internet effectively and correctly. Digital citizenship is an issue that needs to be focused on in order for young people to know their rights and responsibilities in digital environments, to be aware of ethical rules, to think critically and to participate actively for the benefit of society. Social studies course aims to educate the individual as an effective citizen. Consequently, social
\end{abstract}

\footnotetext{
${ }^{1}$ Kastamonu Üniversitesi, Türkiye. Orcid ID: 0000-0002-3135-2557

${ }^{2}$ Kastamonu Üniversitesi, Türkiye. Orcid ID: 0000-0001-8070-6086

${ }^{3}$ Kastamonu Üniversitesi, Türkiye. Orcid ID: 0000-0002-4189-4456

*Bu çalışma,.8th Internatıonal Symposıum On Socıal Studıes Educatıon november 7-9, 2019 Ankara/ Turkey sözlü bildiri olarak sunulan çalıșmadan üretilmiştir.

** Sorumlu Yazar (Corresponding Author): srecepoglu@kastamonu.edu.tr
} 
studies teachers will effectively teach digital citizenship skills. For this reason, it is important to determine the digital citizenship perceptions of social studies teacher candidates. The study group of the study consists of 214 teacher candidates studying in the 1st, $2 \mathrm{nd}, 3 \mathrm{rd}$ and 4 th grades of the faculty of education, Social Studies Education Department of a state university in the 2019-2020 academic year. According to the findings of the study, it was determined that the digital citizenship perception levels of Social Studies teacher candidates were above the medium level.
\end{abstract}

Keywords: Social studies, digital citiizenship, prospective teachers, perception.

\title{
GíRIŞ
}

Son yıllarda dünyada teknolojinin ivme kazanması ve akıllı teknolojik araçların ortaya çıkması ile beraber bilişim ve iletişim teknolojilerinin de çeşitlendiği görülmektedir. Bilişim teknolojisinde yaşanan bu gelişmeler bireyleri dijital dünya kültürünün üyesi olmaya ve gelişmelere ayak uydurmaya zorlamaktadır. Güncel hayatın gereği olarak insanlar dijital kazanımları çeşitli yollarla elde etmektedirler. Bu yollardan birisi de eğitim yoluyla kasıtlı olarak kazandırılmasıdır. Sosyal bilgiler dersi de bireyi hayata hazırlayan bir ders olması sebebiyle bir vatandaşlık dersi olarak düşünülmektedir. Bu yönüyle içinde yaşadığımız bu yüzyılda iyi ve etkili bir vatandaşın temel özelliklerinden birisi de dijital yetkinliklere sahip olmasidir.

Eskiden insanların tek yönlü olarak gerçekleştirdikleri işlemler teknoloji ile birlikte çift boyutlu bir sürece dönüşmüştür. Elektronik ortamda gerçekleşen bu işlemler birtakım karmaşık süreçlere sahiptir ve gerekli kriterler sağlandıktan sonra birey, çevrimiçi ortamda güvenliğini sağlayabilecek asgari yeteneklere sahip olmak zorundadır. Mevzuata uygunluk ve çevrimiçi ortamda güvenliği sağlayabilmek için bireylerin asgari düzeyde bilgi sahibi olmas1 gerekmektedir (Yalçınkaya \& Cibaroğlu, 2019). Bu durum hem ülkemizde hem de dünyada etkin vatandaş olma algısını iyi bir dijital vatandaş olma anlayışına dönüştürmüştür. Yeni neslin iletişim ve bilgi aktarımını teknolojik araçlar yoluyla dijital ortamda gerçekleştirmeye başlaması dijital vatandaşlık kavramını ortaya çıkarmıştır (Çubukçu \& Bayzan, 2013).

Dijital vatandaş, bilgi ve iletişim kaynaklarını başkalarına zarar vermeyecek şekilde kullanabilen, bunları kullanırken eleştirebilen, çevrimiçi davranışlarının etik sonuçlarının bilincinde olan, yaptığı paylaşımlarda olumlu tutumlar gösteren ve başkalarını da bu amaçla teşvik eden vatandaştır (Çubukçu \& Bayzan, 2013; Aslan, 2016). Dijital vatandaşlık ise bilişim araçları ve internetin etik, güvenli ve sorumlu bir kullanımını sağlayacak bilgiye sahip olmak, ilgili tutum ve becerileri sergilemektir (Farmer, 2010; Sakallı \& Çiftci, 2016; Peker Ünal, 2017). İnternetteki yazıları okuyup anlama, yorumlama ve gereken yerlere yönlendirme yeteneğine sahip olma ve interneti etkin olarak kullanma dijital vatandaşl1k ile ilgili bilgi, beceri ve tutumlardır (Mossberger, Tolbert \& McNeal, 2008). Bu bilgi, beceri ve tutumlar; dijital erişim, dijital ticaret, dijital iletişim, dijital okuryazarlık, dijital etik, dijital hukuk, dijital haklar ve sorumluluklar, dijital sağlık ve zindelik ile dijital güvenlik gibi öğelerden oluşur. Dijital vatandaşlığın dokuz alt boyutuna aşağıda yer verilmektedir (Ribble, 2009):

Dijital Erişim: Topluma dijital ortamdan katılım sağlamaktır.

Dijital Ticaret: Online şekilde malların alış ve satışıdır.

Dijital Illetişim: Elektronik ortamda bilgi alışverişi.

Dijital Okuryazarlı: Ne zaman ve nasıl kullanacağını bilerek teknolojiyi kullanma yeteneğidir.

Dijital Etik: Dijital teknoloji kullanıcıları tarafından beklenen davranış standartlarıdır. 
Dijital Hukuk: Yasal haklar ve teknoloji kullanımına ilişkin kısıtlamalardır.

Dijital Haklar ve Sorumluluklar: Bütün dijital teknoloji kullanıcılarının sahip olduğu haklar ve özgürlüklere uygun olan davranış beklentileridir.

Dijital Sağllk ve Zindelik: Dijital teknolojinin kullanımı ile ortaya çıkan fiziksel ve psikolojik sağlık unsurlarıdır.

Dijital Güvenlik: Bütün teknoloji kullanıcılarının ağlarını ve kişisel güvenliklerini garanti altına almak için aldığ tedbirlerdir.

Teknolojinin etkili bir şekilde kullanılabilmesi ancak bu dokuz unsurun gereklerini yerine getirmekle mümkündür (Ribble, 2009). Bu anlamda dijital vatandaşlığın bireylere teknoloji kullanımını öğretmenin yanında onları sürekli gelişen dijital topluma hazırlamayı da hedeflediği söylenebilir (Görmez, 2017). 21. yüzyıl teknolojisiyle birlikte bireylerin çevrimiçi topluma katılma gerekliliği dijital ortamları bireyler için vazgeçilmez hale getirmektedir (Dere \& Yavuzay, 2019).

2018 yılında Millî Eğitim Bakanlığı tarafından revize edilen yeni Sosyal Bilgiler Dersi Öğretim Programı'nda bilim ve teknolojide yaşan değişimler ile bireyin ve toplumun değişen ihtiyaçlarından bahsedilmektedir. Öğrenme ve öğretmedeki teori ve yaklaşımlar da bu gelişmelere bağlı olarak şekillenmektedir. Buna göre artık problem çözebilen, eleştirel düşünebilen, girişimci, kararlı, iletişim becerisine sahip, empati kurabilen, topluma ve kültüre katkı sağlayan bireylerin yetiştirilmesi hedeflenmektedir. Programın özel amaçlarında bu durum "Bilim ve teknolojinin gelişim sürecini ve toplumsal yaşam üzerindeki etkilerini kavrayarak bilgi ve iletişim teknolojilerini bilinçli kullanmaları amaçlanmaktadır." olarak belirtilmektedir. Ayrıca programın yetkinlikler, değerler, kazanımlar ve becerilerinde de dijital vatandaşlık ile ilişki kurulmuştur. Programın 27 becerisinden birisi dijital okuryazarlık, dijital vatandaşlığın alt boyutlarından biridir. Bununla birlikte araştırma, iletişim ve hukuk okuryazarlığı da dijital vatandaşlık ile ilgilidir. Programda yer alan Bilim, Teknoloji ve Toplum öğrenme alanı ile öğrencilerin bilim ve teknolojinin gelişimini fark etmeleri, toplumsal yaşama etkilerini anlamaları ve bilgiye ulaşmada teknolojiyi kullanma becerilerini kazanmaları hedeflenir (Millî Eğitim Bakanlığı, 2018). Bu anlamda sosyal bilgiler dersinin vatandaşlığın dijital boyutunun kazandırılmasında da önemli bir rolü olduğu anlaşılmaktadır (Turan \& Karasu-Avc1, 2018).

Sosyal bilgiler öğretmen adaylarının interneti bilinçli ve etkin bir biçimde kullanabilmesinin temel hedefi vatandaş yetiştirmek olan sosyal bilgiler dersinin dijital vatandaşlık kavramı ile de bağlantılı olduğu anlaşılmaktadır. Dijital vatandaşlık, çevrimiçi ortamı kullanırken bilgi kaynağına eleştirel bakabilen, çevrimiçi etik davranan, teknolojiyi toplumun yararına kullanan, çevrimiçi sağlıklı iletişim kurabilen ve doğru davranışı teşvik eden dijital vatandaşların yetiştirilmesine vurgu yapmaktadır. Bu nedenle, toplumun refahı ve kalkınmasına katkıda bulunacak bilgi, beceri ve değerlere sahip etkin vatandaş yetiştirme amaciyla hareket eden sosyal bilgiler dersine dijital vatandaş yetiştirme konusunda önemli görevler düşmektedir. Nitekim National Council for the Social Studies [NCSS] (1994) sosyal bilgiler dersinin genel amacını "Birbirine bă̆ımlı bir dünyada, kültürel farklılıkları barındıran demokratik bir toplumda yaşayan bireylerin bilgi edinme ve karar verme becerilerini geliştirerek, etkili ve sorumlu vatandaş yetiştirme”" (s. 7) olarak açıklamaktadır. Sosyal bilgiler dersiyle verilmek istenen bilgi, beceri ve tutumlar doğrudan dijital vatandaşlıkla da ilgilidir. Günümüz dünyasının ihtiyaç duyduğu vatandaş profili düşünüldüğünde, dijital vatandaşlık eğitimi ile sosyal bilgiler dersinin ilişkisi ortaya çıkmaktadır. Ayrıca, Sosyal Bilgiler Dersi Öğretim Programı incelendiğinde, programın içerisinde genel ve özel amaçlarda, öğrenme alanlarında, 
kazanımlarda, becerilerde ve değerlerde dijital vatandaşlığa ilişkin unsurların yer aldığı görülmektedir. Özellikle "Türkiye Yeterlikler Çerçevesi” kapsamında 2018 Sosyal Bilgiler Dersi Öğretim Programı'na yansıtılan “dijital yetkinlik” yeterliği sosyal bilgiler dersinde dijital vatandaşlık eğitiminin önemini şu şekilde ortaya koymaktadır:

"Dijital yetkinlik; iş, günlük hayat ve iletişim için bilgi iletişim teknolojilerinin güvenli ve eleştirel şekilde kullanılmasını kapsar. Söz konusu yetkinlik, bilgiye erişim ve bilginin değerlendirilmesi, saklanması, üretimi, sunulmast ve alışverişi için bilgisayarların kullanılması ayrıca internet aracılığılyla ortak ăglara katılım sağlanması ve iletişim kurulmasl gibi temel beceriler yoluyla desteklenmektedir (Milli Ĕ̈itim Bakanlığı [MEB], 2018, s. 5).”

İlgili alan yazın incelendiğinde dijital vatandaşlığa yönelik öğretmen adaylarıyla ilgili (Kocadağ, 2012; Sakall1, 2015; Aslan, 2016; Bakır, 2016; Som-Vural \& Kurt, 2018; Y1lmaz, 2019; Dere \& Yavuzay, 2019), öğretmenlerle ilgili (Tatlı, 2018; Kilci, 2019;), öğrencilerle ilgili (Peker Ünal, 2017), sosyal bilgiler dersinin temel yaklaşımının bilgiyi üretmek ve kullanmak için gereken beceri, kavram ve değerlerle öğrenciyi donatmak olduğunu destekleyen (Ata, 2015; Öztürk, 2015; Acun, 2015) çalışmalara rastlanmaktadır. Ayrıca, 2018 Sosyal Bilgiler Dersi Öğretim Programı'nın uygulanmasında dikkat edilecek hususlar içerisinde de dijital vatandaşlık yeterliliklerini geliştirmek amacıyla, dijital teknolojideki gelişmelere bağlı olarak ortaya çıkan dijital vatandaşlık, e-devlet, sanal ticaret, sosyal medya vb. konulardan ve dijital bölünmüşlük, kimlik hırsızlığ sorunlardan bahsedilmesi gerektiği vurgulanmaktadır. Gençlerin dijital ortamlardaki hak ve sorumluluklarını bilmeleri, etik kuralların bilincinde olmaları, eleştirel düşünebilmeleri, toplumun yararına aktif katılım sağlayabilmeleri için dijital vatandaşlık önem verilmesi gereken bir konudur. $\mathrm{Bu}$ konu ile ilgili ilköğretim düzeyinde öğrencilere gerekli farkındalığ kazandıracak ders sosyal bilgiler dersidir. Bu farkındalığın kazandırılabilmesinde sosyal bilgiler öğretmenleri önemli rol oynamaktadırlar. Öğretmenlerin bu bilinci kazandırabilmeleri ise öğretmen eğitimleri sırasında bu farkındalığı edinip edinmemeleri ile ilgilidir. Bu bağlamda sosyal bilgiler öğretmen adaylarının dijital vatandaşlık algılarının tespit edilmesi önemli görülmektedir.

\section{Araştırmanın Amacı}

Bu çalışma, 2019-2020 eğitim-öğretim yılında bir devlet üniversitesinin eğitim fakültesi 1., 2., 3. ve 4. sınıfta okuyan sosyal bilgiler öğretmen adaylarının dijital vatandaşlık algılarının çeşitli değişkenler açısından incelenmesini amaçlamaktadır. Bu amaç doğrultusunda araştırmanın problem cümlesi: "Sosyal bilgiler öğretmen adaylarının dijital vatandaşlık algıları ne düzeydedir?"

Alt Problemler:

1. Sosyal bilgiler öğretmen adaylarının dijital vatandaşlık algıları cinsiyet değişkenine göre farklılaşmakta mıdır?

2. Sosyal bilgiler öğretmen adaylarının dijital vatandaşlık algıları sınıf düzeyi değişkenine göre farklılaşmakta mıdır?

3. Sosyal bilgiler öğretmen adaylarının dijital vatandaşlık algıları internette geçirilen zaman değişkenine göre farklılaşmakta mıdır? 


\section{YÖNTEM}

Araştırmanın bu bölümünde, araştırma modeli, araştırmanın çalışma grubu, veri toplama araçları ve teknikleri, verilerin toplanması ve analizi ile ilgili açıklamalara yer verilmiştir.

\section{Araştırmanın Modeli}

$\mathrm{Bu}$ araşıtırma tarama modelinde betimsel bir araştırmadır. Betimsel araştırmalarda, mevcut bir durum var olan haliyle tanımlanmaya çalışılır. Tarama modelinde, çok sayıda elemandan oluşan bir evrende, evrenle ilgili genel bir yargıya ulaşmak için, evrenin bütünü veya ondan alınacak bir grup, örneklem üzerinde tarama yapılmaktadır (Karasar, 2009). Bu araştırmada sosyal bilgiler öğretmen adaylarının dijital vatandaşlık algılarının çeşitli değişkenler açısından belirlemek için amacıyla betimsel araştırma modelinden faydalanılmıştır.

\section{Araştırmanın çalışma grubu}

Araştırmanın çalı̧̧ma grubunu 2019-2020 eğitim öğretim yılında bir devlet üniversitesinin Eğitim Fakültesi Sosyal Bilgiler Öğretmenliği bölümü 1., 2., 3. ve 4. sınıfta okuyan 214 öğretmen adayı oluşturmaktadır. Çalışma grubu belirlenirken amaçlı örnekleme türlerinden ölçüt örnekleme türüyle belirlenmiştir. Ölçüt örnekleme, araştırmacı ya da araştırmacılar tarafindan önceden belirlenmiş belli ölçütleri sağlayan bütün durumların çalışılmasına imkân veren gruplardan meydana gelmektedir (Yıldırım ve Şimşek, 2016). Araştırmaya katılan öğretmen adaylarının demografik özelliklerinin frekans ve yüzdelik dağılımları Tablo 1'de verilmiştir.

Tablo 1: Öğretmen Adayların Demografik Özellikleri

\begin{tabular}{|c|c|c|}
\hline Cinsiyet & $\mathbf{N}$ & $\%$ \\
\hline Kadın & 133 & 62,1 \\
\hline Erkek & 81 & 37,9 \\
\hline \multicolumn{3}{|c|}{ Sinıf Düzeyi } \\
\hline $1 . \sin 1 f$ & 52 & 24,3 \\
\hline 2.sinif & 62 & 29 \\
\hline 3.sinif & 54 & 25,2 \\
\hline 4.sinif & 46 & 21,5 \\
\hline \multicolumn{3}{|c|}{ Haftalık İnternet } \\
\hline 1 saat alt1 & 5 & 2,3 \\
\hline $1-2$ saat & 21 & 9,8 \\
\hline 3-4 saat & 53 & 24,8 \\
\hline
\end{tabular}

Araştırmaya katılan sosyal bilgiler öğretmen adaylarının 133'ü kadın, 81'i erkektir. Araştırmayı 1.sinifta okuyan 52, 2.sinifta okuyan 62 , 3.sinifta okuyan 54, 4.sinifta okuyan 46 sosyal bilgiler öğretmen adayı oluşturmaktadır.

\section{Veri Toplama Araci}

Araştırmada veri toplamı aracı olarak Kuş, Z., Güneş, E., Başarmak, U. \& Yakar, H. (2017) tarafından geliştirilen "Gençlere yönelik dijital vatandaşlık ölçeği”" kullanılmıştır. Ölçeğin iç tutarlığı için Cronbach's Alpha güvenirlik katsayıları incelenmiştir. Alt boyutlarında ise, dijital iletişim .814, hak ve sorumluluk .808, eleştirel düşünme .787 , dijital katılım .733, güvenlik .811 , dijital beceriler .743 , etik .792 , dijital ticaret .829 olarak bulunmuştur. Ölçek, İletişim, Hak ve sorumluluk, Eleştirel düşünme, Katılım, Güvenlik, Dijital beceriler, Etik, Ticaret olmak üzere 8 boyuttan ve toplam 49 maddeden oluşmaktadır. 
214 kişiye uygulanan bu çalışmada ölçeğin tamamı için Cronbach's Alpha katsayıs1 .85 bulunmuştur. Alt boyutlarında ise, dijital iletişim .72, hak ve sorumluluk .50, eleştirel düşünme .59 , dijital katılım .77, dijital güvenlik .55, dijital beceriler .83, etik .26, dijital ticaret .74 olarak bulunmuştur. Etik boyutunda 4 madde olduğundan madde sayısının azlığı değerin düşük olmasına neden olmuş olabilir.

\section{Verilerin Analizi}

Araştırmada öğretmen adaylarından elde edilen veriler veri analiz programı kullanılarak analiz edilmiştir. Normallik değeri olarak Shapiro Wilk-w testi sonucu 0,71 iken Kolmogorov Smirnov testi 0,39 bulunmuştur. Bu durumda parametrik testler yapılmış, frekans ve yüzde analizleri yapılmış, aritmetik ortalama ve standart sapma değerleri bulunmuştur. Algılar arasındaki farklılıklar için ise betimsel istetiştik, bağımsız örneklemler için t testi ve tek yönlü varyans analizi kullanılmıştır.

\section{BULGULAR VE YORUM}

$\mathrm{Bu}$ bölümde, öğretmen adaylarının dijital vatandaşlık ölçeğine verdikleri cevaplardan elde edilen bulgulara yer verilmiştir. Bu doğrultuda öğretmen adaylarının ölçeğe verdikleri cevaplar incelenmiş, cinsiyet, sınıf düzeyi ve internete ayrılan zaman açısından değerlendirme yapılmıştır. Buna ek olarak ölçeğin alt boyutları arasındaki ilişki bulunmuş ve tablolar halinde aşağıda sunulmuştur.

Öğretmen adaylarının ölçekten aldıkları iletişim, hak ve sorumluluk, eleştirel düşünme, katılım, güvenlik, dijital beceriler, etik, ticaret ve toplam puanlarına yönelik betimsel istatistiklere Tablo 2'de yer verilmiştir:

Tablo 2. Sosyal Bilgiler Öğretmen Adaylarının Dijital Vatandaşlık Alg1 Düzeyleri

\begin{tabular}{lllll}
\hline Boyutlar & N & En düşük & En Yüksek & Ortalama \\
İletişim (6 madde) & 214 & 9,00 & 27,00 & 18,05 \\
Hak ve Sorumluluk (9 madde) & 214 & 18,00 & 39,00 & 29,63 \\
Eleştirel Düşünme (7madde) & 214 & 10,00 & 30,00 & 21,69 \\
Kat1lım (5 madde) & 214 & 9,00 & 21,00 & 15,02 \\
Güvenlik (6 madde) & 214 & 8,00 & 26,00 & 17,77 \\
Dijital Beceriler (5 madde) & 214 & 11,00 & 25,00 & 20,13 \\
Etik (4 madde) & 214 & 4,00 & 17,00 & 9,48 \\
Ticaret (7 madde) & 214 & 17,00 & 31,00 & 22,43 \\
Toplam (49 madde) & 214 & 118,00 & 196,00 & 154,18 \\
\hline
\end{tabular}

Ölçeğin boyutlarından alınabilecek en düşük, orta ve en yüksek farkındalık puanları incelendiğinde iletişim boyutunda en düşük puan $6(6 \times 1)$, orta puan $15(6 \times 2,5)$ ve yüksek puan $30(6 \times 5)$; hak ve sorumluluk boyutunda en düşük puan $9(9 \times 1)$, orta puan $22,5(9 \times 2,5)$ ve yüksek puan 45(9x5); eleştirel düşünme boyutunda en düşük puan $7(7 \times 1)$, orta puan $17,5(7 \times 2,5)$ ve yüksek puan $35(7 \times 5)$; katılım boyutunda en düşük puan $5(5 \times 1)$, orta puan $12,5(5 \times 2,5)$ ve yüksek puan $25(5 \times 5)$; güvenlik boyutunda en düşük puan $6(6 \times 1)$, orta puan $15(6 \times 2,5)$ ve yüksek puan 30(6x5); dijital beceriler boyutunda en düşük puan $5(5 \times 1)$, orta puan $12,5(5 \times 2,5)$ ve yüksek puan $25(5 \times 5)$; etik boyutunda en düşük puan $4(4 \times 1)$, orta puan $10(4 \times 2,5)$ ve yüksek puan 20(4x5); ticaret boyutunda en düşük puan $7(7 \times 1)$, orta puan $17,5(7 \times 2,5)$ ve yüksek puan $35(7 \times 5)$; ölçeğin tamamında ise en düşük puan $49(49 \times 1)$, orta puan $122,5(49 \times 2,5)$ ve yüksek puan 245(49x5) olarak hesaplanmıştır. Bu puanlardan yola çıkarak Tablo 2'deki bulgular incelendiğinde öğretmen adaylarının iletişim, hak ve sorumluluk, eleştirel düşünme, katılım, 
güvenlik, dijital beceriler, ticaret ve ölçeğin tamamında öğretmen adaylarının puanları orta düzeyin üstündeyken etik boyutunda orta düzeyin altındadır.

Öğretmen adaylarının iletişim, hak ve sorumluluk, eleştirel düşünme, katılım, güvenlik, dijital beceriler, ticaret, etik boyutları ve toplam puanları için cinsiyet değişkeninin farklılaşma düzeyi incelenmiş ve bağımsız t-testi sonucunda elde edilen bulgular Tablo 3 'te sunulmuştur:

Tablo 3. Sosyal Bilgiler Öğretmen Adaylarının Dijital Vatandaşlık Algılarının Cinsiyet Değişkenine Göre Yapılan T testi Sonuçları

\begin{tabular}{|c|c|c|c|c|c|c|c|}
\hline Boyutlar & Cinsiyet & $\mathbf{N}$ & $\overline{\mathrm{x}}$ & SS & SD & $\mathbf{t}$ & $\mathbf{P}$ \\
\hline \multirow[t]{2}{*}{ İletişim } & Kadın & 133 & 17,7444 & 2,76793 & 225 & -2.042 &, 042 \\
\hline & Erkek & 81 & 18,5432 & 2,78859 & & & \\
\hline \multirow{2}{*}{ Hak Sorumluluk } & Kadın & 133 & 29,3233 & 3,51738 & 225 & $-1,641$ &, 102 \\
\hline & Erkek & 81 & 30,1235 & 3,35925 & & & \\
\hline \multirow[t]{2}{*}{ Eleştirel Düşünme } & Kadın & 133 & 21,5940 & 3,34401 & 225 &,- 564 &, 573 \\
\hline & Erkek & 81 & 21,8395 & 2,60508 & & & \\
\hline \multirow[t]{2}{*}{ Katılım } & Kadın & 133 & 14,9323 & 2,26366 & 225 &,- 765 & ,445 \\
\hline & Erkek & 81 & 15,1728 & 2,17825 & & & \\
\hline \multirow[t]{2}{*}{ Güvenlik } & Kadın & 133 & 17,0226 & 2,87219 & 225 & $-4,831$ &, 000 \\
\hline & Erkek & 81 & 18,9877 & 2,90901 & & & \\
\hline \multirow[t]{2}{*}{ Dijital Beceriler } & Kadın & 133 & 20,2331 & 2,86009 & 225 & ,666 & ,506 \\
\hline & Erkek & 81 & 19,9506 & 3,24385 & & & \\
\hline \multirow[t]{2}{*}{ Etik } & Kadın & 133 & 9,0150 & 2,39629 & 225 & $-0,3748$ &, 000 \\
\hline & Erkek & 81 & 10,2469 & 2,22222 & & & \\
\hline \multirow[t]{2}{*}{ Ticaret } & Kadın & 133 & 22,1729 & 2,68698 & 225 & $-1,693$ & ,092 \\
\hline & Erkek & 81 & 22,8395 & 2,95997 & & & \\
\hline \multirow[t]{2}{*}{ Toplam } & Kadın & 133 & 152,0376 & 12,83780 & 225 & -3.212 & 0,002 \\
\hline & Erkek & 81 & 157,7037 & 12,94454 & & & \\
\hline
\end{tabular}

Tablo 3'e göre iletişim, güvenlik, etik ve ölçeğin toplam puanında cinsiyet değişkenine göre bir farklılaşmanın olduğu görülmüştür $(p=0,042 p<0,05 ; p=, 000 p<0,05 ; p=, 000 p<0,05 ; p=0,002$ $\mathrm{p}<0,05)$. Bu farklılaşma erkek öğretmen adayların lehinedir. Yani ilgili boyutlarda erkek öğretmen adaylarının dijital vatandaşlık algı düzeyi daha yüksektir. Buna rağmen hak ve sorumluluk, eleştirel düşünme, katılım, dijital beceriler ve ticaret boyutunda anlamlı bir farklılık görülmemiştir. Fakat ortalamalara bakıldığında hak-sorumluluk, katılım, eleştirel düşünme ticaret boyutlarında erkek öğretmen adaylarının puanı daha yüksektir. Sadece dijital beceriler boyutunda kadın öğretmen adaylarının puanının yüksek olduğu görülmüşsür.

Sınıf düzeyine yönelik olarak öğretmen adaylarının iletişim, hak ve sorumluluk, eleştirel düşünme, katılım, güvenlik, dijital beceriler, etik, ticaret ve toplam puanlarına yönelik bulgular Tablo 4'te yer almaktadir: 


\section{S. RECEPOĞLU}

Tablo 4.Sosyal Bilgiler Öğretmen Adaylarının Dijital Vatandaşlık Alt Boyutlarının Sınıf Düzeyine Göre Betimsel İstatistikleri

\begin{tabular}{|c|c|c|c|c|}
\hline Boyutlar & & $\mathbf{n}$ & $\overline{\overline{\mathbf{x}}}$ & Ss \\
\hline \multirow[t]{5}{*}{ İletişim } & 1.Sinıf & 52 & 18,37 & 2,87 \\
\hline & 2.Sinif & 62 & 18,05 & 2,55 \\
\hline & 3.Sinıf & 54 & 17,94 & 2,43 \\
\hline & 4.Sinıf & 46 & 17,80 & 3,42 \\
\hline & Toplam & 214 & 18,05 & 2,8 \\
\hline \multirow[t]{5}{*}{ Hak Sorumluluk } & 1.Sinıf & 52 & 28,6 & 3,84 \\
\hline & 2.Sinıf & 62 & 29,61 & 3,38 \\
\hline & 3.Sinif & 54 & 29,83 & 2,87 \\
\hline & 4.Sinıf & 46 & 30,57 & 3,60 \\
\hline & Toplam & 214 & 29,63 & 3,47 \\
\hline \multirow[t]{5}{*}{ Eleştirel Düşünme } & 1.Sinif & 52 & 21,71 & 3,01 \\
\hline & 2.Sinıf & 62 & 21,47 & 3,43 \\
\hline & 3.Sinif & 54 & 21,8 & 2,62 \\
\hline & 4.Sinif & 46 & 21,83 & 3,25 \\
\hline & Toplam & 214 & 21,69 & 3,08 \\
\hline \multirow[t]{5}{*}{ Katılım } & 1.Sinıf & 52 & 14,62 & 2,03 \\
\hline & 2.Sinif & 62 & 15,13 & 2,32 \\
\hline & 3.Sinıf & 54 & 14,93 & 2,44 \\
\hline & 4.Sinıf & 46 & 15,46 & 2,03 \\
\hline & Toplam & 214 & 15,02 & 2,23 \\
\hline \multirow{5}{*}{ Güvenlik } & 1.Sinıf & 52 & 17,48 & 3,12 \\
\hline & 2.Sinif & 62 & 17,45 & 2,69 \\
\hline & 3.Sinıf & 54 & 18,3 & 3,46 \\
\hline & 4.Sinif & 46 & 17,89 & 2,85 \\
\hline & Toplam & 214 & 17,77 & 3,03 \\
\hline \multirow[t]{5}{*}{ Dijital Beceriler } & 1.Sinif & 52 & 20,06 & 3,44 \\
\hline & 2.Sinif & 62 & 19,86 & 3 \\
\hline & 3.Sinif & 54 & 19,96 & 2,75 \\
\hline & 4.Sinıf & 46 & 20,76 & 2,78 \\
\hline & Toplam & 214 & 20,13 & 3,00 \\
\hline \multirow[t]{5}{*}{ Etik } & 1.Sinıf & 52 & 8,65 & 2,14 \\
\hline & 2.Sinif & 62 & 9,57 & 2,43 \\
\hline & 3.Sinıf & 54 & 10,02 & 2,72 \\
\hline & 4.Sinıf & 46 & 9,67 & 2,06 \\
\hline & Toplam & 214 & 9,48 & 2,40 \\
\hline \multirow[t]{5}{*}{ Ticaret } & 1.Sinıf & 52 & 22,04 & 2,91 \\
\hline & 2.Sinif & 62 & 22,50 & 2,77 \\
\hline & 3.Sinif & 54 & 22,35 & 2,60 \\
\hline & 4.Sinif & 46 & 22,85 & 2,98 \\
\hline & Toplam & 214 & 22,43 & 2,805 \\
\hline \multirow[t]{5}{*}{ Toplam } & 1.Sinif & 52 & 151,52 & 14,47 \\
\hline & 2.Sinif & 62 & 153,63 & 13,55 \\
\hline & 3.Sinif & 54 & 155,13 & 10,52 \\
\hline & 4.Sinif & 46 & 156,83 & 13,57 \\
\hline & Toplam & 214 & 154,18 & 13,14 \\
\hline
\end{tabular}

Tablo 4 incelendiğinde hak ve sorumluluk ve etik puanlarının farklılaştığı görülmektedir. Bunun yanında iletişim, eleştirel düşünme, katılım, güvenlik, dijital beceriler, ticaret ve toplam puanlarına çok yakın olduğu görülmektedir. 
Öğrencilerin aldıkları puanların sınıf düzeyi değişkeni farklılaşma durumunun incelenmesi için tek yönlü ANOVA yapılmıştır. Analiz sonuçları Tablo 5'te sunulmuştur:

Tablo 5. Sosyal Bilgiler Öğretmen Adaylarının Dijital Vatandaşlık Alt Boyutlarının Sınıf Düzeyine Göre ANOVA Testi

\begin{tabular}{|c|c|c|c|c|c|c|c|}
\hline \multicolumn{2}{|l|}{ Boyutlar } & \multirow{2}{*}{$\begin{array}{l}\mathbf{K ~ T} \\
8,548\end{array}$} & \multirow{2}{*}{$\begin{array}{l}\text { Sd } \\
3\end{array}$} & \multirow{2}{*}{$\begin{array}{l}\text { KO } \\
2,849\end{array}$} & \multirow{2}{*}{$\begin{array}{l}\mathbf{F} \\
, 361\end{array}$} & \multicolumn{2}{|l|}{$\mathbf{p}$} \\
\hline \multirow[t]{3}{*}{ Iletişim } & Gurup Aras1 & & & & & ,781 & \\
\hline & Gurup Içi & 1656,985 & 210 & 7,890 & & & \\
\hline & Toplam & 1665,533 & 213 & & & & \\
\hline \multirow[t]{3}{*}{ Hak_Sorumluluk } & Gurup Arası & 98,060 & 3 & 32,687 & 2,779 &, 042 & \\
\hline & Gurup Içi & 2470,033 & 210 & 11,762 & & & \\
\hline & Toplam & 2568,093 & 213 & & & $1 / 4$ & \\
\hline \multirow[t]{3}{*}{ Eleştirel_Düşünme } & Gurup Arası & 4,547 & 3 & 1,516 &, 158 & ,925 & \\
\hline & Gurup Içi & 2017,477 & 210 & 9,607 & & & \\
\hline & Toplam & 2022,023 & 213 & & & & \\
\hline \multirow[t]{3}{*}{ Katılım } & Gurup Aras1 & 18,491 & 3 & 6,164 & 1,244 & ,295 & \\
\hline & Gurup Içi & 1040,392 & 210 & 4,954 & & & \\
\hline & Toplam & 1058,883 & 213 & & & & \\
\hline \multirow[t]{3}{*}{ Güvenlik } & Gurup Arası & 26,266 & 3 & 8,755 & ,951 & ,417 & \\
\hline & Gurup Içi & 1934,051 & 210 & 9,210 & & & \\
\hline & Toplam & 1960,318 & 213 & & & & \\
\hline \multirow[t]{3}{*}{ Dijital_Beceriler } & Gurup Arası & 24,777 & 3 & 8,259 & ,912 & 436 & \\
\hline & Gurup Içi & 1900,816 & 210 & 9,052 & & & \\
\hline & Toplam & 1925,593 & 213 & & & & \\
\hline \multirow[t]{3}{*}{ Etik } & Gurup Aras1 & 53,324 & 3 & 17,775 & 3,174 &, 025 & \\
\hline & Gurup Içi & 1176,101 & 210 & 5,600 & & $1 / 2$ & $1 / 3-$ \\
\hline & Toplam & 1229,425 & 213 & & & $1 / 4$ & \\
\hline \multirow[t]{3}{*}{ Ticaret } & Gurup Arası & 16,631 & 3 & 5,544 & ,701 & ,552 & \\
\hline & Gurup Içi & 1659,673 & 210 & 7,903 & & & \\
\hline & Toplam & 1676,304 & 213 & & & & \\
\hline \multirow[t]{3}{*}{ Toplam } & Gurup Aras1 & 757,743 & 3 & 252,581 & 1,473 & 223 & \\
\hline & Gurup Içi & 36018,150 & 210 & 171,515 & & & \\
\hline & Toplam & 36775,893 & 213 & & & & \\
\hline
\end{tabular}

Tablo 5'e göre öğretmen adaylarının hak ve sorumluluk ve etik puanları arasında anlamlı fark bulunmuş diğer boyutlara ait puanlarında anlamlı farklılık bulunmamıştır $(\mathrm{F}=2,779, \mathrm{p}<, 05$; $\mathrm{F}=3,174, \mathrm{p}<, 05)$. Öğretmen adaylarının sınıf düzeyi değişkeni hak ve sorumluluk ve etik puanlarının hangi gruplarda farklılaştığını bulmak için LSD testi karşılaştırması yapılmıştır. Buna göre hak ve sorumluluk boyutunda 1. ve 4. sinıfları arasında 4.sinıfların lehine, etik boyutunda 1. ve 2. sinıflar arasında, 1. ve 3. sinıflar arasında ve 1. ve 4.sinıflar arasında olduğu ve bu farklılaşmaların 2, 3. ve 4. sınıfların lehine olduğu görülmüsstür.

Haftalık internet kullanımı değişkenine yönelik olarak öğretmen adaylarının iletişim, hak ve sorumluluk, eleştirel düşünme, katılım, güvenlik, dijital beceriler, etik, ticaret ve toplam puanlarına yönelik bulgular Tablo 6' da yer almaktadır: 


\section{S. RECEPOĞLU}

Tablo 6. Sosyal Bilgiler Öğretmen Adaylarının Dijital Vatandaşlık Alt Boyutlarının Haftalık İnternet Kullanımına Göre Betimsel İstatistikleri

\begin{tabular}{|c|c|c|c|c|}
\hline & & $\mathbf{n}$ & $\overline{\mathbf{x}}$ & Ss \\
\hline \multirow[t]{5}{*}{ İletişim } & 1saat Alt1 & 5 & 18,60 & 3,65 \\
\hline & 1-2 Saat & 21 & 17,91 & 1,73 \\
\hline & 3-4 Saat & 53 & 17,76 & 3,55 \\
\hline & 4 ve Üstü & 135 & 18,16 & 2,58 \\
\hline & Toplam & 214 & 18,05 & 2,8 \\
\hline \multirow[t]{5}{*}{ Hak Sorumluluk } & 1saat Alt1 & 5 & 28,40 & 6,03 \\
\hline & 1-2 Saat & 21 & 31,29 & 3,73 \\
\hline & 3-4 Saat & 53 & 28,60 & 3,31 \\
\hline & 4 ve Üstü & 135 & 29,82 & 3,29 \\
\hline & Toplam & 214 & 29,63 & 3,47 \\
\hline \multirow[t]{5}{*}{ Eleştirel Düşünme } & 1saat Alt1 & 5 & 21 & 3,54 \\
\hline & 1-2 Saat & 21 & 21,91 & 2,70 \\
\hline & 3-4 Saat & 53 & 21,26 & 3,34 \\
\hline & 4 ve Üstü & 135 & 21,84 & 3,03 \\
\hline & Toplam & 214 & 21,69 & 3,08 \\
\hline \multirow[t]{5}{*}{ Katılım } & 1saat Alt1 & 5 & 14,00 & 3,08 \\
\hline & 1-2 Saat & 21 & 15,29 & 2,92 \\
\hline & 3-4 Saat & 53 & 15,32 & 2,18 \\
\hline & 4 ve Üstü & 135 & 14,90 & 2,1 \\
\hline & Toplam & 214 & 15,02 & 2,23 \\
\hline \multirow[t]{5}{*}{ Güvenlik } & 1saat Alt1 & 5 & 16,60 & 3,72 \\
\hline & 1-2 Saat & 21 & 16,67 & 2,76 \\
\hline & 3-4 Saat & 53 & 16,85 & 2,94 \\
\hline & 4 ve Üstü & 135 & 18,34 & 2,97 \\
\hline & Toplam & 214 & 17,77 & 3,03 \\
\hline \multirow[t]{5}{*}{ Dijital Beceriler } & 1saat Alt1 & 5 & 19,40 & 2,70 \\
\hline & 1-2 Saat & 21 & 20,33 & 2,58 \\
\hline & 3-4 Saat & 53 & 19,15 & 3,27 \\
\hline & 4 ve Üstü & 135 & 20,50 & 2,91 \\
\hline & Toplam & 214 & 20,13 & 3,00 \\
\hline \multirow[t]{5}{*}{ Etik } & 1saat Alt1 & 5 & 10,60 & 2,70 \\
\hline & 1-2 Saat & 21 & 9,33 & 2,13 \\
\hline & 3-4 Saat & 53 & 9,32 & 2,74 \\
\hline & 4 ve Üstü & 135 & 9,53 & 2,30 \\
\hline & Toplam & 214 & 9,48 & 2,40 \\
\hline \multirow[t]{5}{*}{ Ticaret } & 1saat Alt1 & 5 & 21,20 & 3,35 \\
\hline & 1-2 Saat & 21 & 22,43 & 2,80 \\
\hline & 3-4 Saat & 53 & 21,77 & 2,49 \\
\hline & 4 ve Üstü & 135 & 22,73 & 2,88 \\
\hline & Toplam & 214 & 22,43 & 2,81 \\
\hline \multirow[t]{5}{*}{ Toplam } & 1saat Alt1 & 5 & 149,80 & 10,76 \\
\hline & 1-2 Saat & 21 & 155,14 & 13,12 \\
\hline & 3-4 Saat & 53 & 150,04 & 14,66 \\
\hline & 4 ve Üstü & 135 & 155,82 & 12,31 \\
\hline & Toplam & 214 & 154,18 & 13,14 \\
\hline
\end{tabular}

Tablo 6 incelendiğinde öğretmen adaylarının hak ve sorumluluk, dijital beceriler ve toplam puanlarının farklılaștığı görülmektedir. Bunun yanında iletişim, eleștirel düşünme, katılım, güvenlik, etik ve ticaret puanlarının çok yakın olduğu görülmektedir. 
Öğretmen adaylarının aldıkları puanların haftalık internet kullanımı değişkenine göre farklılaşma durumunun incelenmesi için tek yönlü ANOVA yapılmıştır. Analiz sonuçları Tablo 7'de sunulmuştur:

Tablo 7. Sosyal Bilgiler Öğretmen Adaylarının Dijital Vatandaşlık Alt Boyutlarının Haftalık İnternet Kullanımına Göre ANOVA Testi Sonuçları

\begin{tabular}{|c|c|c|c|c|c|c|}
\hline & & $\mathbf{K} \mathbf{T}$ & Sd & KO & $\mathbf{F}$ & $\mathbf{p}$ \\
\hline \multirow[t]{3}{*}{ İletişim } & Gurup Arası & 8,297 & 3 & 2,766 &, 350 & ,789 \\
\hline & Gurup içi & 1657,236 & 210 & 7,892 & & \\
\hline & Toplam & 1665,533 & 213 & & & \\
\hline \multirow[t]{3}{*}{ Hak Sorumluluk } & Gurup Arası & 125,558 & 3 & 41,853 & 3,598 &, 014 \\
\hline & Gurup içi & 2442,535 & 210 & 11,631 & & $1-2 / 3-4$ \\
\hline & Toplam & 2568,093 & 213 & & & saat \\
\hline \multirow[t]{3}{*}{ Eleştirel Düşünme } & Gurup Arası & 16,179 & 3 & 5,393 &, 565 & ,639 \\
\hline & Gurup içi & 2005,845 & 210 & 9,552 & & \\
\hline & Toplam & 2022,023 & 213 & & & \\
\hline \multirow[t]{3}{*}{ Katılım } & Gurup Arası & 13,302 & 3 & 4,434 & ,891 & ,447 \\
\hline & Gurup içi & 1045,581 & 210 & 4,979 & & \\
\hline & Toplam & 1058,883 & 213 & & & \\
\hline \multirow[t]{3}{*}{ Güvenlik } & Gurup Arası & 121,333 & 3 & 40,444 & 4,618 & ,065 \\
\hline & Gurup içi & 1838,985 & 210 & 8,757 & & \\
\hline & Toplam & 1960,318 & 213 & & & \\
\hline \multirow[t]{3}{*}{ Dijital Beceriler } & Gurup Arası & 73,186 & 3 & 24,395 & 2,766 &, 043 \\
\hline & Gurup içi & 1852,407 & 210 & 8,821 & & $4 \ddot{s} s t u ̈ / 3-4$ \\
\hline & Toplam & 1925,593 & 213 & & & saat \\
\hline \multirow[t]{3}{*}{ Etik } & Gurup Aras1 & 8,352 & 3 & 2,784 & ,479 & ,697 \\
\hline & Gurup içi & 1221,073 & 210 & 5,815 & & \\
\hline & Toplam & 1229,425 & 213 & & & \\
\hline \multirow[t]{3}{*}{ Ticaret } & Gurup Aras1 & 42,219 & 3 & 14,073 & 1,809 & ,147 \\
\hline & Gurup içi & 1634,085 & 210 & 7,781 & & \\
\hline & Toplam & 1676,304 & 213 & & & \\
\hline \multirow[t]{3}{*}{ Toplam } & Gurup Arası & 1388,863 & 3 & 462,954 & 2,747 &, 044 \\
\hline & Gurup içi & 35387,029 & 210 & 168,510 & & 3-4 /4 üstü \\
\hline & Toplam & 36775,893 & 213 & & & saat \\
\hline
\end{tabular}

Tablo 7'ye göre öğretmen adaylarının hak ve sorumluluk, dijital beceriler ve toplam puanları arasında anlamlı fark bulunmuş diğer boyutlara ait puanlarında anlamlı fark bulunmamıştır $(\mathrm{F}=2,766, \mathrm{p}<, 05 ; \mathrm{F}=2,747, \mathrm{p}<, 05 ; \mathrm{F}=3,598, \mathrm{p}<, 05)$. Öğretmen adaylarının haftalık internet kullanımı açısından hak ve sorumluluk, dijital beceriler ve toplam puanlarının hangi gruplarda farklılaştığını bulmak için LSD testi karşılaştırması yapılmıştır. Buna göre hak ve sorumluluk boyutunda 1-2 ve 3-4 saat zaman geçirenler arasında 1-2 saat zaman geçirenlerin lehine olmuş, dijital beceriler boyutunda 4 saat ve üstü ile 3-4 saat zaman geçirenler arasında 4 saat ve üstü zaman geçirenler lehine, toplam puanlarında 3-4 saat ile 4 saat ve üstü saat geçirenler arasında 4 saat ve üstü geçirenler lehine olduğu görülmüştür.

\section{TARTIŞMA VE ÖNERILER}

$\mathrm{Bu}$ araştırmanın amacı, sosyal bilgiler öğretmen adaylarının dijital vatandaşlık algı düzeylerini çeşitli değişkenler açısından belirlemektir. Genel olarak, sosyal bilgiler öğretmen adaylarının dijital vatandaşlık algılarına bakıldığında orta düzeyin üstünde olduğu saptanmıştır. Buna göre, teknolojinin hızla geliştiği ve dijital yeterliliğe sahip olmanın önemli olduğu günümüzde sosyal 
bilgiler öğretmen adaylarının dijital vatandaşlığa yönelik farkındalıklarının olduğu söylenebilir. Alan yazın çalışmalarında öğretmen adaylarının dijital vatandaşlık algılarının yüksek olduğu tespit edilmiştir. Araştırmanın alt boyutları kapsamında bakıldığında sosyal bilgiler öğretmen adaylarının dijital vatandaşlık algıları iletişim, hak ve sorumluluk, eleştirel düşünme, katılım, güvenlik, dijital beceriler, ticaret boyutunda orta düzeyin üstündeyken etik boyutunda orta düzeyin altındadır. Buna göre etik boyutunda dijital ortamlarda diğerlerinin haklarına saygılı ve sorumlu davranma konusunda öğretmen adaylarının algılarının yeterli olmadığı söylenebilir. Öğretmen adaylarının dijital vatandaşlık ile ilgili bilinçsiz olması ve bununla ilgili eğitim almamaları tehlikeli sonuçlara yol açabilmektedir (Farmer, 2010). Bununla birlikte, Sincar (2011) tarafindan yapılan çalışmada da etik boyutunun düşük olduğu bulgusuna ulaşılmıştır.

Sosyal bilgiler öğretmen adaylarının dijital vatandaşlık algılarının iletişim, güvenlik, etik ve ölçeğin toplam puanında cinsiyet değişkenine göre bir farklılaşma olduğu görülmüştür. Bu farklılaşma erkek öğretmen adayların lehinedir. Buna rağmen hak ve sorumluluk, eleştirel düşünme, katılım, dijital beceriler ve ticaret boyutunda anlamlı bir farkl1lık görülmemiştir. Fakat ortalamalara bakıldığında hak-sorumluluk, katılım, eleştirel düşünme, ticaret boyutlarında erkek öğretmen adaylarının puanı daha yüksektir. Sadece dijital beceriler boyutunda kadın öğretmen adaylarının puanının yüksek olduğu görülmüştür. Alan yazında araştırmanın bulguları ile benzer çalışmalara rastlanmaktadır (Kocadağ, 2012; Som-Vural, 2016; Özerbaş \& Kuralbayeva, 2018; Yılmaz, 2019). Diğer taraftan, Sakallı (2015) Aslan (2016), Çakmak \& Aslan (2018), Kabataş (2019) tarafından yapılan araştırma bulgularında dijital vatandaşlık düzeyi cinsiyete göre farklılaşmamaktadır.

Yapılan analizler sonucunda sosyal bilgiler öğretmen adaylarının dijital vatandaşlık algılarının sınıf düzeylerine göre anlamlı bir şekilde farklılaşmadığı sonucuna ulaşılmıştır. Bu sonuçlar doğrultusunda sınıf düzeyinin sosyal bilgiler öğretmen adaylarının dijital vatandaşlık algılarını etkilemediği söylenebilir. Alan yazında bu bulguyu destekleyen çalışmalar olduğu görülmektedir (Çukurbaşı \& İşman 2014; Sakallı, 2015; Sakallı \& Çiftçi, 2016; Aslan, 2016; Özerbaş \& Kuralbayeva, 2018; Çakmak \& Aslan, 2018). Araştırmanın alt boyutları kapsamında bakıldığında, sosyal bilgiler öğretmen adaylarının dijital vatandaşlık algılarının sınıf düzeyi değişkenine göre hak ve sorumluluk ve etik puanlarının arasında anlamlı fark bulunmuş diğer boyutlara ait puanlarında anlamlı fark bulunmamıştır. Bunun yanında iletişim, eleştirel düşünme, katılım, güvenlik, dijital beceriler, ticaret ve toplam puanlarına çok yakın olduğu görülmektedir. Sosyal bilgiler öğretmen adaylarının dijital vatandaşlık algılarının sınıf düzeyi değişkenine göre hak ve sorumluluk boyutunda 1 . ve 4. sınıfların arasında 4. sınıfların lehine olmuş, etik boyutunda 1. ve 2 . sinıflar arasında, 1. ve 3. sinıflar arasında ve 1. ve 4. sinıflar arasında olduğu ve bu farklılaşmaların 2. 3. ve 4. sınıfların lehine olduğu görülmüş̧ür. 1. sınıf sosyal bilgiler öğretmen adaylarının hak ve sorumluluk ve etik boyutunda dijital vatandaşlık algıları düş̧ütür. $\mathrm{Bu}$ bulgular doğrultusunda, hak ve sorumluluk ve etik boyutunda sosyal bilgiler öğretmen adaylarının sınıf düzeyi artıkça dijital vatandaşlık algılarının da arttığı söylenebilir. Diğer bir ifadeyle, smıf düzeyi, ölçeğin hak ve sorumluluk ve etik boyutunda sosyal bilgiler öğretmen adaylarının dijital vatandaşlık algılarını etkilemektedir.

Sosyal bilgiler öğretmen adaylarının dijital vatandaşlık alt boyutlarının haftalık internet kullanımına göre hak ve sorumluluk, dijital beceriler ve toplam puanlarının farklılaştı̆̆ görülmektedir. Bunun yanında iletişim, eleştirel düşünme, katılım, güvenlik, etik ve ticaret puanlarının çok yakın olduğu görülmektedir. Sosyal bilgiler öğretmen adaylarının dijital vatandaşlık alt boyutlarının haftalık internet kullanımına göre, hak ve sorumluluk boyutunda 12 ve 3-4 saat zaman geçirenler arasında 1-2 saat zaman geçirenlerin lehine olmuş, dijital 
beceriler boyutunda 4 ve üstü ile 3-4 saat zaman geçirenler arasında 4 ve üstü zaman geçirenlerin lehine, toplam puanlarında 3-4 saat ile 4 ve üstü saat geçirenlerin arasında 4 ve üstü geçirenlerin lehine olduğu görülmüştür. İnternet kullanım süreleri arttıkça öğretmen adaylarının teknolojik gelişmelere uyumlarının arttığ d düşünülebilir. Farkın bu öğretmen adayları lehine olması uzun süre dijital cihazlarla ve teknolojilerle vakit geçirmeleri, dijital vatandaşlık bilincinin de gelişmeye başladığının göstergesi olarak düşünülebilir. Gündüz ve Özdinç (2008)'in internette fazla zaman geçiren kullanıcıların dijital ortamlarda daha başarılı oldukları bulgusu da bu farkı desteklemektedir. Araştırmayla ilgili alan yazında ortalama internet kullanma süresiyle dijital vatandaşlık ölçeği puanları arasında anlamlı fark bulunan çalışmalara rastlanmaktadır (Kocadağ, 2012; Aslan, 2016; Sakallı \& Çiftçi, 2016; Çakmak \& Aslan, 2018; Onursoy, 2018; Kabataş, 2019), İlgili çalışmalarda dijital vatandaşlık puanı yüksek olanların uzun süre internete bağlandığ 1 ve ortalama internet kullanımının yüksek olduğu görülmektedir.

Araştırmadan elde edilen sonuçlar doğrultusunda aşağıdaki öneriler getirilmiştir.

- Araştırmanın nitel veya karma araştırma yöntemleriyle gerçekleştirilmesi öğretmenlerin dijital vatandaşlığa ilişkin algılarının derinlemesine değerlendirilmesi etkili olabilir.

- $\mathrm{Bu}$ çalışmada dijital vatandaşlık alt boyutlarından bazılarının düşük bazılarının ise yüksek ortalamaya sahip olmalarının nedenleri araştırılabilir.

- Öğretmenlerle gerçekleştirilecek nicel araştırmaların farklı örneklemlerle gerçekleştirilmesi öğretmenlerin dijital vatandaşlığa ilişkin algılarına yönelik genel bir çerçeve sunabilir.

\section{KAYNAKÇA}

Acun, İ. (2015). Bilgisayar destekli öğretim uygulamaları. Ed. Cemil Öztürk, Sosyal bilgiler öğretimi, demokratik vatandaşlık eğitimi içinde (s.344-367). Pegem Akademi.

Aslan, S. (2016). İlköğretim sosyal bilgiler öğretmen adaylarını dijital vatandaşlık davranışlarını bazı değişkenler açısından incelenmesi (Firat, Dicle, Siirt, Adıyaman üniversiteleri örneği), (Yayımlanmamış, yüksek lisans tezi). T.C. Frrat Üniversitesi, Eğitim Bilimleri Enstitüsü, Elazı̆̆g.

Ata, B. (2015). Sosyal bilgiler öğretim programı. Ed. Cemil Öztürk, Sosyal bilgiler öğretimi, demokratik vatandaşlı eğitimi içinde (s.33-47). Pegem Akademi.

Aygün, M. (2019). Sosyal bilgiler öğretmenlerinin ve sosyal bilgiler öğretmen adaylarının dijital vatandaşllk durumlarının incelenmesi, (Yayımlanmamış yüksek lisans tezi). Yıldız Teknik Üniversitesi, İstanbul

Bakır, E. (2016). Sınıf ögrretmeni adaylarının dijital vatandaşlık seviyelerinin dijital vatandaşlık alt boyutlarına göre incelenmesi, (Yayımlanmamış yüksek lisans tezi). Karadeniz Teknik Üniversitesi, Eğitim Bilimleri Enstitüsü, Trabzon.

Çakmak, Z. ve Aslan, S. (2018). Sosyal bilgiler öğretmen adaylarının dijital vatandaşlık davranışlarının bazı değişkenler açısından incelenmesi. Adıyaman Üniversitesi Eğitim Bilimleri Dergisi, 8(1), 72-99.

Çubukçu, A. ve Bayzan, Ş. (2013). Türkiye'de dijital vatandaşlık algısı ve bu algıyı internetin bilinçli, güvenli ve etkin kullanımı ile artırma yöntemleri. Middle Eastern \& African Journal of Educational Research, 5, 148-174.

Çukurbaşı, B. ve İşman, A. (2014). Öğretmen adaylarının dijital yerli özelliklerinin incelenmesi (Bartın Üniversitesi Örneği). Bartın University Journal of Faculty of Education, 3(1), 28-54.

Dere, İ. ve Yavuzay, M. (2019). Sosyal bilgiler öğretmen adaylarının dijital vatandaşlık göstergelerinin incelenmesi, Manas Sosyal Araştırmalar Dergisi, 8(3), 2400-2414.

Farmer, L. (2010). 21. Century standarts for information literacy. Leadership, 39(4), 20-22. 
Görmez, E. (2017). İlkokul sosyal bilgiler programının dijital vatandaşlık ve alt boyutları açısından yeterliliği. International Journal of Social Science 2(60), 1-15.

Gündüz, Ş. ve Özdinç, F. (2008). İlköğretim ikinci kademe öğrencilerinin internet öz-yeterlikleri. 8th International Educational Technology Conference, 06-09 May, (ss. 1144-1148). Eskişehir: Anadolu Üniversitesi

Kabataş, S. (2019). Öğretmen adaylarının dijital vatandaşlık algılarının yaşam boyu öğrenme tutumları ve eögrenmeye hazır bulunuşluğu açısından değgerlendirilmesi, (Yayımlanmamış yüksek lisans tezi). Bartın Üniversitesi, Eğitim Bilimleri Enstitüsü, Bartın.

Karasar, N. (2009). Bilimsel araştırma yöntemi. Nobel Yayıncılık

Kilci, Z. (2019). Sosyal bilgiler öğretmenlerinin dijital vatandaşlı̆̆a yönelik görüşleri ve uygulamalarl, (Yayımlanmamış yüksek lisans tezi). Anadolu Üniversitesi, Eğitim Bilimleri Enstitüsü, Eskişehir.

Kocadă̆, T. (2012). Öğretmen adaylarının dijital vatandaşlık düzeylerinin belirlenmesi, (Yayınlanmamış yüksek lisans tezi). Karadeniz Teknik Üniversitesi, Eğitim Bilimleri Enstitüsü, Trabzon.

Kuş, Z, Güneş, E, Başarmak, U, Yakar, H. (2017). Development of a digital citizenship scale for youth: A validity and reliability study. Journal of Computer and Education Research, 5(10), 298-316

Millî Eğitim Bakanlığı. (2018). Sosyal Bilgiler Dersi Öğretim Programı. Devlet Kitapları Basım Evi.

Mossberger, K., Tolbert, C. J. ve McNeal, R. S. (2008). Digital citizenship: The internet, society, and participation. MIT Press.

National Council for the Social Studies, (2017). NCSS Themes. www.socialstudies.org

Onursoy, S. (2018). Üniversite gençliğinin dijital okuryazarlık düzeyleri: Anadolu üniversitesi öğrencileri üzerine bir araştırma. Gümüşhane Üniversitesi İletişim Fakültesi Elektronik Dergisi, 6(2), 989-1013.

Özerbaş, M. A. ve Kuralbayeva, A. (2018). Türkiye ve Kazakistan öğretmen adaylarının dijital okuryazarlık düzeylerinin değerlendirilmesi. Muğla Sitkı Koçman Üniversitesi Eğitim Fakültesi Dergisi, 5(1), 16-25.

Öztürk, C. (2015). Sosyal Bilgiler: Toplumsal yaşama disiplinler arası bir bakış. Ed. Cemil Öztürk, Sosyal bilgiler ögretimi, demokratik vatandaşlık eğitimi içinde (s.1-31). Pegem Akademi

Peker Ünal, D. (2017). Bir öğretim programındaki dijital vatandaşlık öğeleri ve ortaöğretim öğrencilerinin dijital vatandaşlık ögelerine sahip olma durumları. Karaelmas Journal of Educational Sciences, 5, 180-195.

Ribble, M. (2009). Raising a digital child: A digital citizenship handbook for parents, Washington DC: The International Society for Technology in Education (ISTE).

Sakallı, H. (2015). Sınıf öğretmeni adaylarının dijital vatandaşlık düzeyleri ile siber zorbalık ĕ̌ilimleri arasındaki ilişkinin incelenmesi, (Yayımlanmamış yüksek lisans tezi). Adnan Menderes Üniversitesi, Sosyal Bilimler Enstitüsü, Aydın.

Sakallı, H. ve Çiftçi, S. (2016). Sınıf öğretmeni adaylarının dijital vatandaşlık düzeyleri ile siber zorbalık eğilimleri arasındaki ilişkinin incelenmesi: Adnan Menderes Üniversitesi Örneği, Ĕ̈itim Teknolojisi Kuram ve Uygulama, 6(2), 100-119.

Sincar, M. (2011). An analysis of prospective teachers' digital citizenship behaviour norms. International Journal of Cyber Ethics in Education, 1(2), 25-40

Som-Vural, S. (2016). Üniversite öğrencilerinin baklş açısıyla dijital vatandaşlık göstergelerinin incelenmesi, (Yayınlanmamış doktora tezi). Anadolu Üniversitesi, Eğitim Bilimleri Enstitüsü, Eskişehir.

Som Vural, S. ve Kurt, A. (2018). Üniversite öğrencilerinin bakış açısıyla dijital vatandaşlık göstergelerinin incelenmesi. Eğitim Teknolojisi Kuram ve Uygulama, 8(1), 60-80.

Tatlı, A. (2018). Öğretmenlerin dijital vatandaşlık düzeylerinin bilgi okuryazarlığı ile internet ve bilgisayar kullanım öz yeterlikleri bağlamında değerlendirilmesi, (Yayımlanmamış yüksek lisans tezi). T.C. Necmettin Erbakan Üniversitesi, Eğitim Bilimleri Enstitüsü, Konya.

Turan, S. ve Karasu-Avcı, E. (2018). 2018 Sosyal bilgiler öğretim programının dijital vatandaşlık bağlamında incelenmesi. Ĕ̈itim ve Yeni Yaklaşımlar Dergisi, 1(1), 28-38

Yalçınkaya, B. ve Cibaroğlu, M. O. (2019), Dijital vatandaşlık algısının incelenmesi: Ampirik bir değerlendirme, BMIJ, 7(4): 1188-1208 
E. KARASU AVCI,

Sosyal Bilgiler Öğretmen Adaylarının Dijital Vatandaşlı

M. FAIZ \&

Algilarinin Belirlenmesi

S. RECEPOĞLU

Yıldırım, A. ve Şimşek, H. (2016). Sosyal bilimlerde nitel araştırma yöntemleri. Seçkin Yayıncılık.

Yılmaz, M. (2019). Öğretmen adaylarının dijital vatandaşllk düzeylerinin belirlenmesı, (Yayımlanmamış yüksek lisans tezi). Mersin Üniversitesi, Eğitim Bilimleri Enstitüsü, Mersin. 


\section{EXTENDED ABSTRACT}

\section{Determination of Digital Citizenship Perceptions of Social Studies Teacher Candidates}

\section{Introduction}

Developments in the field of information and communication significantly affect the society. The rapid development of information communication technologies has affected all fields as well as the studies on citizenship and the concepts of citizenship related to technology have emerged. One of them is the concept of digital citizenship. Digital citizenship generally covers the rights and responsibilities regarding the use of technology, ethical rules and the ability to use the internet effectively and correctly. Digital citizenship is an issue that needs to be focused on in order for young people to know their rights and responsibilities in digital environments, to be aware of ethical rules, to think critically and to participate actively for the benefit of society. For this reason, it is important to determine the digital citizenship perceptions of social studies teacher candidates.

\section{Method}

The research is in descriptive survey model. The study group of the research consists of 214 teacher candidates studying in 1st.2.nd 3rd.4th. grade level of department of Social Studies Teaching at Kastamonu University Education Faculty in the academic year of 2019-2020. As a data collection tool in the research, it was used "Digital citizenship scale for youth" developed by Kuş, Z., Güneş, E., Başarmak, U. \& Yakar, H. (2017). The scale consists a total of 49 items. Descriptive statistics, $t$ test, one way analysis of variance (ANOVA) was used according to the characteristics of research problems.

\section{Result}

It has been observed that there is a difference according to the gender variable in the communication, security, ethics and the total score of the digital citizenship perceptions of Social Studies teacher candidates. As a result of the analysis, it was concluded that the digital citizenship perceptions of Social Studies teacher candidates did not differ significantly according to theirg rade levels. It is observed that the sub-dimensions of digital citizenship of Social Studies teacher candidates differ according to their weekly internet usage in terms of rights and responsibilities, digital skills and total scores. Besides, it is seen that communication, critical thinking, participation, safety, ethics and trade scores are very close.

\section{Discussion}

In general, considering the digital citizenship perceptions of Social Studies teacher candidates, it was found to be above the middle level. Accordingly, it can be said that there is an awareness of Social Studies teacher candidates for digital citizenship in today's world where technology is developing rapidly and having digital competence is important. Conducting the research with qualitative or mixed research methods may be effective in determining teachers' perceptions of digital citizenship. In this study, the reasons why some of the sub-dimensions of digital citizenship are low and some have high average can be investigated. Conducting quantitative 
E. KARASU AVCI,

studies with different study groups can provide a general framework for teachers' perceptions of digital citizenship.

\section{(c) (†)(9)}

"International Journal of New Approaches in Social Studies - IJONASS" is licensed under a Creative Commons Attribution-NonCommercial-ShareAlike 4.0 International License. 